Int. J. Dev. Biol. 52: 503-510 (2008)

doi: $10.1387 / \mathrm{ijdb} .082696 \mathrm{hf}$

\title{
Regulating the acrosome reaction
}

\author{
HARVEY M. FLORMAN*, MELISSA K. JUNGNICKEL and KEITH A. SUTTON \\ Department of Cell Biology, University of Massachusetts Medical School, Worcester, MA, USA
}

\begin{abstract}
The acrosome reaction is a secretory event that must be completed by the sperm of many animal species prior to fusion with eggs. In mammals, exocytosis in triggered by ZP3, a glycoprotein component of the egg pellucida, following gamete contact. ZP3 promotes a sustained influx of $\mathrm{Ca}^{2+}$ into sperm that is necessary for the acrosome reaction. Here, we discuss the mechanism by which ZP3 generates $\mathrm{Ca}^{2+}$ entry, as well as the upstream events leading to this influx and downstream processes that couple it with exocytosis.
\end{abstract}

KEY WORDS: acrosome reaction, signal transduction calcium channel, TRPC channel, PI3, kinase

\section{Introduction}

The sperm of many animals, including those of all mammals, contain a single secretory vesicle, or acrosome, in the anterior portion of the head. The contents of this vesicle are released during the early stages of sperm-egg interaction through an exocytotic process known as the acrosome reaction.

Exocytosis represents a key control point in the process of fertilization. Sperm must complete the acrosome reaction in order both to penetrate the egg zona pellucida and to fuse with the egg plasma membrane. However, if exocytosis is completed prematurely then sperm cannot enter the cumulus oophorus surrounding the egg (Cummins and Yanagimachi, 1986). Thus, the acrosome reaction functions as a behavioral switch, converting sperm into a state in which they are competent to interact with eggs. Moreover, it is an irreversible step and thus differs from other modes of regulation that operate within the female reproductive tract. Thus, the initiation of acrosome reactions must be strictly regulated and coordinated spatially and temporally with the availability of eggs.

This discussion will consider the control of the acrosome reaction by the egg zona pellucida, and will retain a narrow focus on the role of sperm intracellular $\mathrm{Ca}^{2+}\left(\mathrm{Ca}^{2+}{ }_{\mathrm{i}}\right)$ activity in this process, on the mechanism by which egg-derived agonists regulate that cation, and on the downstream targets of agonistinduced $\mathrm{Ca}^{2+}$ entry. As such, this line of investigation follows from suggestions and thoughts in an influential and still relevant review by Garbers and Kopf (Garbers and Kopf, 1980). The signal transduction mechanisms that link zona pellucida stimulation to sperm exocytosis are complex, involving pathways in addition to $\mathrm{Ca}^{2+}$. Readers interested in more general information concerning the mammalian acrosome reaction or on events in non-mamma- lian species may wish to consult other sources (Yanagimachi, 1994; Florman and Ducibella, 2006; Darszon et al., 2006; Roldan and Shi, 2007).

\section{Capacitation as a regulator of the acrosome reaction}

Mammalian sperm are released by the male in a functionally restricted state and must complete a process of priming, or capacitation, within the female reproductive tract before acquiring the ability to fertilize eggs. Capacitation is associated with complex changes in the biochemical, physiological and cellular properties of the sperm. As a result of this process, sperm develop novel patterns of motility, including hyperactivation and oriented motility towards chemoattractants from the female reproductive tract, and also acquire the ability to undergo a zona pellucidaevoked acrosome reaction. A number of changes in the intracellular ionic environment of sperm occur during capacitation. These and other events associated with capacitation have been extensively reviewed recently (Florman and Ducibella, 2006; Eisenbach and Giojalas, 2006; Gadella and Visconti, 2006) and the present discussion of capacitation is not intended to be comprehensive. Rather, it will focus on alterations in sperm membrane potential that may regulate the ability of sperm to undergo acrosome reactions.

Sperm membrane potential hyperpolarizes during capacitation. Fluorescent probes report population-averaged values that are in the range of -25 to $-40 \mathrm{mV}$ for uncapacitated cells and that rise to $\sim-60 \mathrm{mV}$ following incubation under capacitating conditions (Zeng etal., 1995; Arnoult etal., 1999; Munoz-Garay etal., 2001).

Abbreviations used in this paper: CNG, cyclic nucleotide gated channel; TRPC, transient receptor potential channel; ZP zona pellucida.

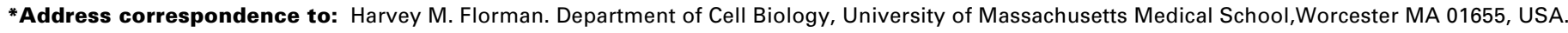
Fax: +1-508-856-1033. e-mail: harvey.florman@umassmed.edu
} 
Single cell measurements revealed that sperm sort into two subpopulations during incubation: one group exhibits weak hyperpolarization to $-45 \mathrm{mV}$ and a second group shifts to $\sim-80 \mathrm{mV}$. Only those sperm in the strongly hyperpolarizing group $(-80 \mathrm{mV})$ were capacitated, as assessed both by chlortetracycline fluorescence and by the ability to undergo a zona pellucida-induced acrosome reaction (Arnoult etal., 1999). This hyperpolarization is associated with an enhanced contribution of $\mathrm{K}^{+}$permeability to membrane potential (Zeng et al., 1995), which may result from an increased $\mathrm{K}^{+}$channel activity or the closing of other conductance pathways. In this regard, a number of $\mathrm{K}^{+}$channels are present in sperm, although specific channels have not yet been linked to hyperpolarization (Darszon et al., 2006; Navarro et al., 2007). There is, additionally, evidence for a decreased $\mathrm{Na}^{+}$conductance that may contribute to hyperpolarization. Finally, ion transport pathways such as the $\mathrm{Na}^{+} / \mathrm{HCO}^{-}$cotransporter and the cystic fibrosis transmembrane regulator participate in the regulation of membrane potential during capacitation (Demarco et al., 2003; Xu et al., 2007; Hernandez-Gonzalez et al., 2007).

It has been suggested that hyperpolarization regulates the ability of sperm to undergo zona pellucida-evoked acrosome reactions (Arnoult et al., 1999). Zonae pellucidae trigger a transient $\mathrm{Ca}^{2+}$ entry through low voltage-activated channels (see below). These channels exhibit voltage-dependent inactivation and, at the prevailing membrane potential of uncapacitated sperm, dwell in an inactivated state from which openings are rare. Hyperpolarization to $-80 \mathrm{mV}$, such as occurs during capacitation, shifts those channels into a closed state, from which opening and current flow can occur following a depolarization (Perez-Reyes, 2003). According to this suggestion, the relatively depolarized membrane potential of uncapacitated sperm prevents premature acrosome reactions by holding low voltage-activated channels in a reluctant state, while hyperpolarization primes sperm, permitting a response respond to depolarizing signals by acrosome reacting (Arnoult et al., 1999).

\section{Acrosome reactions}

\section{Triggers}

This discussion focuses on the activation of sperm following contact with the zona pellucida or interaction with soluble extracts of the zona pellucida. The evidence for an acrosome reactioninducing agonist activity in the zona pellucida has been reviewed frequently (Wassarman et al., 2001; Florman and Ducibella, 2006) and can be summarized as follows. Most of the sperm in the ampulla of the oviduct that are not associated with the egg/ cumulus complex have intact acrosomes (Bryan, 1974; Cummins and Yanagimachi, 1982; Suarez et al., 1983) while sperm observed moving through the cumulus matrix either have intact acrosomes or may show initial signs of exocytosis (Cummins and Yanagimachi, 1982; Yanagimachi, 1994). In addition, sperm appear to make initial contact with the zona pellucida in vivoprior to initiation of acrosome reactions (Crozet, 1984; Crozet and Dumont, 1984) and can initiate and complete the acrosome reaction following zona pellucida contact in vitro (Gwatkin, 1976; Gwatkin etal., 1976; Saling etal., 1979; Saling and Storey, 1979). These and other observations suggest that the zona pellucida is the site of the acrosome reaction during the fertilization process.

Agonist activity was demonstrated in soluble extracts of the zona pellucida (Florman et al., 1982; Bleil and Wassarman, 1983). Mouse ZP3 retained agonist activity following purification whereas the other zona pellucida proteins, ZP1 and ZP2, did not (Bleil and Wassarman, 1983). Other observations that support the assignment of agonist activity to ZP3 include its presence at the site of fertilization, the direct binding of this protein to sperm (Thaler and Cardullo, 1996) and the loss of agonist activity following fertilization (Bleil and Wassarman, 1983). In addition, the effects of pharmacological inhibitors on the acrosome reaction induced by purified ZP3 and by soluble extracts of the zona pellucida recapitulate the response of sperm undergoing the acrosome reaction on structurally intact zonae pellucidae (Arnoult etal., 1999), suggesting that the same signal transduction mechanisms are activated in all cases. It should be noted that zonae pellucidae of many mammalian species are constructed from four proteins, however in mouse ZP4 has become a pseudogene (Conner et al., 2005). The question of whether ZP3 also functions independently as the agonist in zonae pellucidae containing all four components is, at present, unresolved.

A number of pharmacological agents and biological fluids will also induce acrosome reactions, yet are of uncertain biological significance. One informative example is that of progesterone, which is released by cumulus cells and so may be encountered by sperm in the vicinity of eggs at the time of fertilization. High concentrations (micromolar) of progesterone promote acrosome reactions (Osman et al., 1989) and potentiate the agonist effects of zona pellucida in vitro (Roldan et al., 1994). Yet, at lower concentrations (picomolar to nanomolar), or when presented as a concentration gradient to simulate sperm approach to the egg, the effects of progesterone are on the modulation of flagellar motility and chemotaxis rather than upon acrosome reactions (Harper et al., 2004; Harper and Publicover, 2005; Teves et al., 2006). The question of a physiological role of progesterone in control of acrosome reactions remains unresolved. Similarly, agonist activity is present in follicular fluid and released with eggs during ovulation, but it is uncertain how such factors would be captured by the oviduct following ovulation or be retained in the vicinity of the egg within the oviduct. The remainder of this discussion will focus on the mechanism of action of ZP3.

\section{From ZP3 stimulation to a $\mathrm{Ca}^{2+}$ response}

Sperm interaction with the zona pellucida triggers a number of initial responses which are required in order to produce the sustained $\mathrm{Ca}^{2+}$ influx that leads to the acrosome reaction (see below). An elevation of intracellular $\mathrm{pH}_{\mathrm{i}}$ is reported using fluorescent indicator dyes (Florman et al., 1989; Rockwell and Storey, 2000) and may be driven by a G protein-dependent pathway (Arnoult et al., 1996b). The heterotrimeric GTP-binding proteins, $\mathrm{G}_{\mathrm{i} 1}$ and $\mathrm{G}_{\mathrm{i} 2}$, are activated in sperm by the zona pellucida (Endo et al., 1988; Ward et al., 1994a; Ward et al., 1994b) and the zona pellucida-dependent intracellular alkalinization does not occur when G protein stimulation is inhibited by treatment with pertussis toxin (Florman et al., 1989; Arnoult et al., 1996b). Transient alkalinization, by treatment with a permeant weak base, bypasses the pertussis toxin block in ZP3 signaling and allows both $\mathrm{Ca}^{2+}$ influx and acrosome reactions (Arnoult et al., 1996b). This suggests elevation of $\mathrm{pH}_{\mathrm{i}}$ is the key step in signal transduction that is blocked by inhibition of ZP3-activated G proteins in sperm. A specific role of $\mathrm{pH}_{\mathrm{i}}$ in $\mathrm{ZP} 3$ action has not been assigned, but may, 
speculatively, include an enhancement of $\mathrm{Ca}^{2+}$ signals (Babcock and Pfeiffer, 1987; Arnoult et al., 1996b).

Zonae pellucidae also activate sperm phospholipase C (PLC)(Roldan et al., 1994; Roldan and Shi, 2007). Following targeted deletions of the p/cd4 gene in mice, sperm cannot generate a sustained $\mathrm{Ca}^{2+}{ }_{i}$ influx or acrosome reaction in response to zona pellucida stimulation (Fukami etal., 2001; Fukami et al., 2003). Other PLC isoforms are also present in the sperm head (Walensky and Snyder, 1995) and may contribute to ZP3 responses. PLC hydrolyzes phosphatidylinositol-1,4-bisphosphate (PIP2) to produce two products: inositol-1,4,5-triphosphate (IP3), which gates IP3 receptors present in the acrosomal membrane (Walensky and Snyder, 1995); and diacylglycerol. Plcd4 may be regulated by $\mathrm{Ca}^{2+}$, by PIP2 and by a high molecular weight $\mathrm{G}$ protein, while other isoforms are controlled by G proteins (Rebecchi and Pentyala, 2000; Rhee, 2001; Fukami, 2002), but the mechanism by which ZP3 regulates PLC activity has not been defined.

Finally, zonae pellucidae trigger a transient elevation of $\mathrm{Ca}^{2+}{ }_{i}$. $\mathrm{Ca}^{2+}$ increases from resting levels in the nanomolar range to micromolar values within $50 \mathrm{msec}$ and then, in the continuous presence of ZP3, relaxes to basal levels during the next $200 \mathrm{msec}$ (Arnoult et al., 1999). This activation time course and effects of pharmacological antagonists suggest that this transient $\mathrm{Ca}^{2+}$ entry is carried by a low voltage-activated $\mathrm{Ca}^{2+}$ channel, most likely a member of the $\mathrm{Ca}_{\mathrm{v}} 3$ family (Arnoult et al., 1996a; Arnoult et al., 1999). All three members of the $\mathrm{Ca}_{\mathrm{v}} 3$ family are present in sperm, with $\mathrm{Ca}_{\mathrm{v}} 3.1$ and 3.2 detected in the sperm head and so plausibly localized for a role in the acrosome reaction (Trevino et al., 2004; Jimenez-Gonzalez et al., 2005; Florman and Ducibella, 2006; Publicover etal., 2007; Escoffier etal., 2007). However, the disruption of the genes that encode either $\mathrm{Ca}_{v} 3.1$ or 3.2 channels does not affect fertility and the concerted disruption of several $\mathrm{Ca}_{\mathrm{v}}$ genes has not been reported (Chen et al., 2003; Stamboulian et al., 2004; Escoffier et al., 2007). Thus, the identity of this ZP3activated channel is not yet resolved.

Also unresolved is the mechanism by which ZP3 activates low voltage activated currents. Voltage-dependent activation of these channels has been reviewed extensively (Perez-Reyes, 2003). ZP3 produces a membrane potential depolarization that is sufficiently strong to activate $T$ channels, but this response is slow and might be expected to trigger voltage-dependent inactivation before there is significant current flow (Arnoult et al., 1996b). Alternative mechanisms of $\mathrm{Ca}_{\mathrm{v}}$ channel activation have been described (Perez-Reyes, 2003), and these channels in sperm may also be regulated by either tyrosine phosphorylation (Arnoult et al., 1997) or by calmodulin (Lopez-Gonzalez et al., 2001).

These upstream elements of ZP3 signal transduction cannot complement each other and appear to function as parallel, essential processes rather than in series. As a result, it has been suggested that these early steps are organized as a bifurcated pathway, with separate limbs consisting of transient $\mathrm{Ca}^{2+}$ entry and of $\mathrm{G}$ protein and $\mathrm{pH}$ responses. Both limbs must operate for effective transmission. These signals are integrated at the level of the sustained $\mathrm{Ca}^{2+}$ entry (Arnoult et al., 1996b; Florman and Ducibella, 2006).

\section{Scuplting a sustained $\mathrm{Ca}^{2+}$ elevation}

A role of $\mathrm{Ca}^{2+}$ in the zoná pellucida-evoked acrosome was anticipated based on observations that the frequency of agonist- independent acrosome reactions (the so-called "spontaneous" acrosome reaction) was strictly dependent on the presence of extracellular $\mathrm{Ca}^{2+}$ (Yanagimachi and Usui, 1974) and the understanding of the general role of that cation in exocytosis (Katz and Miledi, 1967; Douglas, 1968; Neher et al., 1987). Although it was understood by the early 1980 s that an acrosome reaction-inducing agonist activity was present in the zona pellucida (Florman and Storey, 1982) and that ZP3 accounted for this activity (Bleil and Wassarman, 1983), the heterogeneity of sperm populations and other technical difficulties (reviewed by Florman and Ducibella, 2006; Gadella and Visconti, 2006) prevented direct examination of this question until the introduction, in the mid-1980s, of ionselective indicator dyes that could be loaded into cells passively (Grynkiewicz et al., 1985) and of image analysis techniques that permitted events in single cells to be resolved.

In considering $\mathrm{Ca}^{2+}$ triggering of acrosome reactions, it should be recalled that $\mathrm{Ca}^{2+}{ }_{\mathrm{i}}$ also controls other behavioral responses in sperm, including capacitation (Fraser et al., 1995; Visconti et al., 1995), hyperactived flagellar motility (Kamiya and Witman, 1984; Suarez et al., 1993; Suarez and Ho, 2003; Marquez and Suarez, 2004) and, possibly, chemotaxis (Spehr et al., 2003; Fukuda et al., 2004). It is necessary to regulate these cellular functions separately and several mechanisms are expected to contribute to that signaling isolation. First, sperm have a number of $\mathrm{Ca}^{2+}$ conducting channels and transport proteins. These include both high- and, as discussed previously, low- voltage activated channels $\left(\mathrm{Ca}_{\mathrm{v}}{ }^{1-3}\right)$, members of the TRPC family of $\mathrm{Ca}^{2+}$-conducting cation channels, cyclic nucleotide-gated (CNG) channels, and the Catsper channels in the plasma membrane, as well as IP3 receptors and, possibly, ryanodine receptors on intracellular membranes (reviewed by Felix, 2005; Jimenez-Gonzalez et al., 2006; Publicover et al., 2007). Differences in the mechanisms of activation and inactivation of these channels provide a means of selective activation. Second, the unique biophysical properties of various channels, taken together with their spatial distribution in sperm (Walensky and Snyder, 1995; Westenbroek and Babcock, 1999; Wennemuth etal., 2000; Ren etal., 2001; Quill et al., 2001; Florman and Ducibella, 2006), facilitates the coupling of specific influx pathways with cellular responses. Finally, behavioral responses are encoded in the spatiotemporal pattern of ionic responses, thereby permitting individual processes to be driven separately. $\mathrm{Ca}^{2+}{ }_{\mathrm{i}}$ oscillations drive flagellar bending patterns while capacitation is associated with linear, low-slope increases (Florman and Ducibella, 2006; Publicover et al., 2007). In contrast, the signature response of to stimulation with ZP3 or with unfractionated extracts of the zona pellucida is a sustained elevation of $\mathrm{Ca}^{2+}$, as shown in studies in bovine (Florman et al., 1989), mouse (Arnoult et al., 1996a; Fukami et al., 2003), and hamster models (Shirakawa and Miyazaki, 1999). Fluorescent indicators report that $\mathrm{Ca}^{2+}$ levels in capacitated sperm rise from basal levels of 100-150 nM to a peak of $400-600 \mathrm{nM}$, which is maintained or relaxes slowly in the continuous presence of agonist (Florman etal., 1989; Florman, 1994; O'Toole etal., 2000; Fukami et al., 2003; Florman and Ducibella, 2006). This sustained rise precedes exocytosis and agents that block this $\mathrm{Ca}^{2+}{ }_{i}$ response also inhibit the acrosome reaction (reviewed by Florman and Ducibella, 2006).

It was initially suggested, based on inhibitor studies, that sustained entry of $\mathrm{Ca}^{2+}$ into sperm during ZP3 stimulation was 
due to the activation of an L-type $\left(\mathrm{Ca}_{v} 1\right)$ high voltage-activated $\mathrm{Ca}^{2+}$ channel (Florman et al., 1992). However, it was not understood at that time that sperm also had low voltage-activated, $\mathrm{Ca}_{\mathrm{v}} 3$ channels; that transient $\mathrm{Ca}^{2+}$ entry through those $\mathrm{Ca}_{\mathrm{v}} 3$ channels was an essential pre-requisite for the sustained phase of response, such that inhibitors of $\mathrm{Ca}_{v} 3$ block downstream processes, including the sustained $\mathrm{Ca}^{2+}$ rise (reviewed by Florman and Ducibella, 2006), or that there was considerable overlap in the pharmacology of $\mathrm{Ca}_{\mathrm{v}} 1$ and $\mathrm{Ca}_{\mathrm{v}} 3$ channel classes (PerezReyes, 2003). In addition, it was shown that the sustained influx pathway had a pharmacological profile that differed from that of $\mathrm{Ca}_{\mathrm{v}} 3$ channel (O'Toole et al., 2000). Thus, neither $\mathrm{Ca}_{\mathrm{v}} 1$ or $\mathrm{Ca}_{\mathrm{v}} 3$ channels account for the sustained phase of influx.

More recently, attention has focused on the role of TRPC (canonical transient receptor potential) channels in ZP3 signaling. The seven members of the TRPC family form $\mathrm{Ca}^{2+}$-conducting channels that are widely expressed in animal cells and contribute to PLC-dependent $\mathrm{Ca}^{2+}$ entry (Montell, 2005; Putney, 2007). Several TRPC channels are expressed in sperm, with TRPC1, C2 and C5 are located in the anterior head where sperm interact with the zona pellucida and where acrosome reaction signaling occurs (Trevino et al., 2001; Jungnickel et al., 2001; Castellano et al., 2003; Sutton et al., 2004; Stamboulian et al., 2005). A substantial fraction of the ZP3-evoked $\mathrm{Ca}^{2+}$ influx into mouse sperm is conducted by TRPC2, as a function-blocking antibody against the second extracellular loop of that channel inhibits both $80-85 \%$ of the sustained $\mathrm{Ca}^{2+}{ }_{\mathrm{i}}$ response and also blocks the acrosome reaction (Jungnickel et al., 2001). ZP3 may activate TPRC2 through a store-operated mechanism (O'Toole et

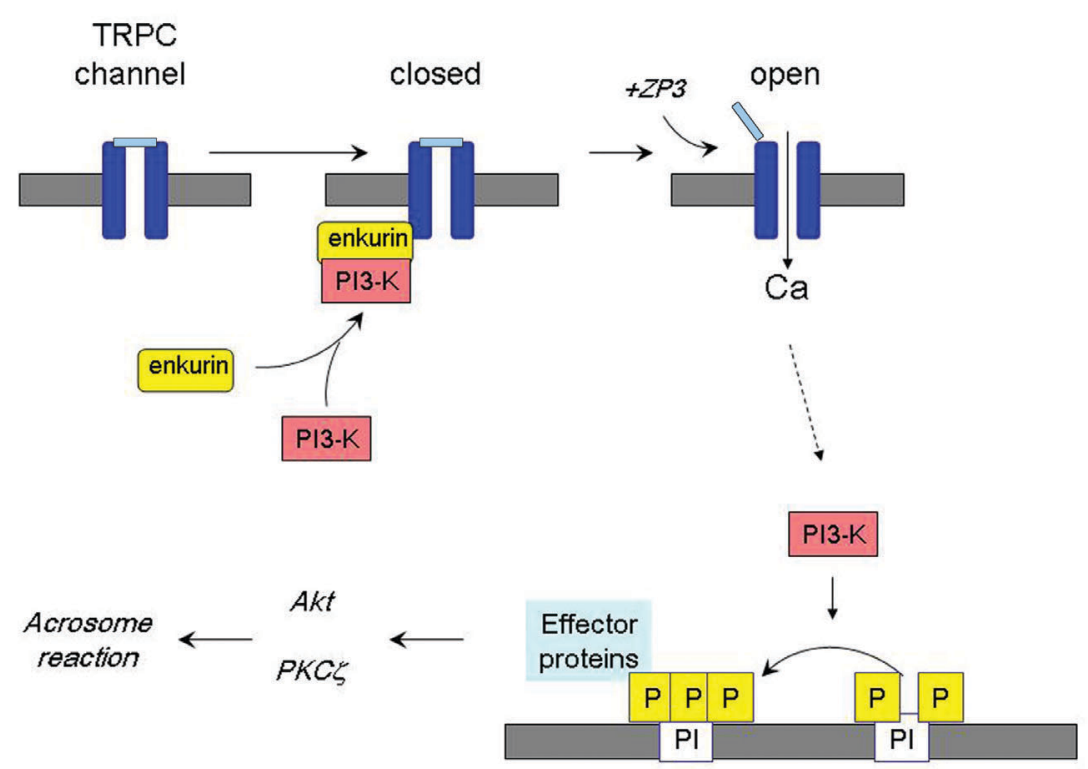

Fig. 1. Model of the late events of the mouse sperm acrosome reaction. Enkurin is a scaffold protein that binds PI3 kinase to sperm transient receptor potential channels (TRPC). Sperm contact with the zona pellucida results in ZP3 activation of TRPC channels, leading to both $\mathrm{Ca}^{2+}$ entry and to activation of PI3 kinase. The resulting D3phosphorylation of (PIP2) (phosphatidylinositol-4,5-bisphosphate) leads to the local accumulation of PIP3 (phosphatidylinositol-3,4-5-triphosphate). PIP3 provides docking sites for proteins with appropriate lipid binding domains and results in the activation of the serine/theonine protein kinases, Akt (Protein Kinase B) and PKC $\zeta$. These protein kinases mediate the downstream stages of sperm exocytosis. See text for details. al., 2000; Jungnickel et al., 2001), although interaction with IP3 receptors on the adjacent acrosomal membrane is also plausible (Kiselyov et al., 1998). In addition, a component of the ZP3induced $\mathrm{Ca}^{2+}$ entry cannot be inhibited by the TRPC2 functionblocking antibody (Jungnickel et al., 2001), suggesting that other channels may also contribute to this influx. This is also consistent with the fertility of mice following the disruption of the trpc2gene, and of humans, where TRPC2 is a pseudogene (Stowers et al., 2002; Leypold et al., 2002; Montell, 2005). It is tempting to speculate that other channels in the anterior head, including other TRPC channels (see above) as well as additional channel families (reviewed by Florman and Ducibella, 2006), account for this $\mathrm{Ca}^{2+}$ entry and fertility when TRPC2 is absent.

\section{From $\mathrm{Ca}^{2+}$ entry to exocytosis}

An acute rise in $\mathrm{Ca}^{2+}{ }_{i}$ triggers the release of the acrosomal granule, pointing to a role of $\mathrm{Ca}^{2+}$-binding proteins in the downstream events the follow $\mathrm{Ca}^{2+}$ influx. Such downstream targets are expected to be localized within the spatial domains of that $\mathrm{Ca}^{2+}$ elevation. The recognition that TRPC channels mediate a major component of the sustained $\mathrm{Ca}^{2+}$ entry that is triggered by ZP3 resulted in an effort to identify $\mathrm{Ca}^{2+}$ binding proteins associated with these channels.

This lead to the identification of enkurin, multidomain protein containing a proline-rich $\mathrm{N}$-terminal region with predicted $\mathrm{SH} 3$ and WW ligand motifs and a C-terminal domain that binds TRPC2. It also binds TRPC1 and C5 (but not TRCP3), although those interaction sites have not yet been mapped (Sutton et al., 2004). This binding specificity corresponds to the functional and sequence classes of TRPC channels-(Nilius et al., 2007), suggesting that enkurin binds the TRPC1/4/5 and TRPC2 classes, but not the TRPC3/6/7 class. Enkurin also contains an IQ motif that binds $\mathrm{Ca}^{2+}$ calmodulin, but not apocalmodulin, and therefore associates a $\mathrm{Ca}^{2+}$ sensor with the inner face of a $\mathrm{Ca}^{2+}$-conducting ion channel (Sutton et al., 2004). Enkurin has the anticipated sequence characteristics of an adapter protein that binds $\mathrm{SH} 3$ and WW domain cargo to ZP3-activated TRPC channels, thereby assembling a signaling module at the site of ZP3 action.

One such cargo protein appears to be 1phosphatidylinositol-3-kinase (PI3K). The SH3 domain of p85, the regulatory subunit of PI3K, binds to the sequence PKKPAVP (residues 83-89 of mouse enkurin)(Sutton et al., 2004). A role of PI3K in ZP3 signal transduction was unanticipated, yet several lines of evidence indicate that phosphatidylinositol signaling pathways are activated during the initiation of the acrosome reaction (Fig. 1; Jungnickel et al., 2007).

An increase in the levels of phosphatidylinositol3,4,5-triphosphate (PIP3), one product of PI3K catalytic activity, can be detected within $30 \mathrm{sec}$ of ZP3 treatment, whereas the production of other PI3K products, such as phosphatidylinositol-3-phosphate, could not be detected. The mechanism of PI3 kinase activation is unresolved. It is tempting to speculate that $\mathrm{Ca}^{2+}$ entry through TRPC channels permits enkurin/ $\mathrm{Ca}^{2+}$-calmodulin to associate with activated 
channels, and thereby translocates PI3 kinase to the plasma membrane.

- Both the ZP3-dependent accumulation of PIP3 and the induction of acrosome reactions were inhibited by two different PI3K antagonists, wortmannin and LY294002.

- PI3K subunits and PTEN, the phosphoinositide D3-phosphatase are both present in the acrosomal crescent of mouse sperm, thus co-localizing with both TRPC2 (and also with TRPC1 and C5) and with enkurin.

- Inhibitors of phosphoinositide D3-phosphatases, when used in the absence of ZP3, lead to PIP3 accumulation and to acrosome reactions, with both effects blocked by PI3K antagonists. Yet, the effects of phosphatase inhibitors and zona pellucida agonists on acrosome reactions were not additive, pointing to a common mechanism (Jungnickel et al., 2007).

Two inferences can be drawn from these observations. First, the effects of phosphatase inhibitors point to the constitutive operation of a phosphoinositide phosphorylation/dephosphorylation cycle in capacitated sperm. Cycling provides a means for rapid, finely-controlled enzymatic response (Newsholme and Start, 1973). Second, elevations of PIP3 are necessary and sufficient for the induction of the acrosome reaction.

PIP3 is typically a trace component of the membranes of unstimulated cells and is produced locally at the site of PI3 kinase activation. Proteins containing specific PIP3 binding domains, including a $\mathrm{PH}$ or $\mathrm{PX}$ domain, are then recruited to the membrane to permit the local assembly of a number of signal transduction modules (Cantley, 2002; Newton, 2003). In this regard, two protein kinases, Akt (protein kinase B, PKB) and the atypical protein kinase $\mathrm{C}, \mathrm{PKC}$, that are effectors of PIP3 (Cantley, 2002; Newton, 2003; Fayard et al., 2005) have been shown to act downstream of PIP3 during ZP3 signaling in sperm (Jungnickel et al., 2007). These Ser/Thr kinases are located in the acrosomal crescent region of the sperm head and inhibitors block the ZP3induced acrosome reaction. Additionally, in the case of PKB/Akt there is direct evidence for activation by the zona pellucida (Jungnickel et al., 2007). A major activation mechanism for PKB/ Akt is through the sequential phosphorylation of Thr-308 and of Ser-473, with PDK1 (the phosphoinositide-dependent protein kinase-1) acting as the Thr-308 kinase (Chan et al., 1999). Using phosphorylation state-specific antibodies, it was found that soluble extracts of the zona pellucida produced a $>2$-fold increase in Thr308 phosphorylation in sperm and that this effect was blocked by the PI3 kinase inhibitor, wortmannin (Jungnickel et al., 2007).

A plausible activation mechanism then is the stimulation of $\mathrm{PI} 3$ kinase by the zona pellucida leads to local accumulation of PIP3, and then to the recruitment of PKD1 to that site as a result of the association of its PH domain with PIP3 (Alessi and Cohen, 1998; Lizcano and Alessi, 2002). Localization at the membrane permits PDK1 access to substrate proteins. Among such substrates are the AGC superfamily of protein kinases, including both PKB/Akt and PKC $\zeta$ (Newton, 2003). Thus, a common mechanism can account for the activation of both of these protein kinases by ZP3. In this regard, PDK1 is present in sperm, in both the acrosomal crescent and in the flagellum (Jungnickel et al., 2007).

PI3 kinase pathways, including PKB/Akt and PKC $\zeta$, have previously been linked to exocytosis in somatic systems (Fig. 1), either through the control of vesicle trafficking or by interaction with SNARE proteins and other elements of the secretory machin- ery (Cousin etal., 2003; Czech, 2003; Viard etal., 2004; Bezzerides et al., 2004; Bose et al., 2004; Hodgkinson et al., 2005a; Hodgkinson et al., 2005b; Evans et al., 2006). One focus of future work will be the identification of kinase substrates in sperm, and their role in the evoked acrosome reaction.

\section{Closing comments}

Understanding of the mechanisms by which the zona pellucida regulates the acrosome reaction is central to models of fertilization, and also shapes developing strategies for the control of fertility. Efforts were made in this narrative to outline our present knowledge of ZP3 signaling, specifically with regard to the regulation of $\mathrm{Ca}^{2+}{ }_{\mathrm{i}}$ and to downstream effectors of that ionic response. The stages of this signaling mechanism include: 1 ) early events, such as $\mathrm{G}$ protein activation, intracellular alkalinization, and transient $\mathrm{Ca}^{2+}$ entry; 2) these lead to a sustained influx of $\mathrm{Ca}^{2+}$, a major component of which is carried by TRPC channels in mouse sperm; and 3) downstream events, including the activation of phosphoinositide-dependent protein kinases. It is speculated that these downstream processes are linked to $\mathrm{Ca}^{2+}$ entry by enkurin, a TRPC and PI3 kinase-binding protein.

More generally, this discussion has focused on one aspect of the control of sperm behavior by the egg. As such, the pioneering work of David Garbers in this general area is still recognized and appreciated. His studies on chemosensory response mechanisms in echinoderm sperm and also on mammalian sperm function (Garbers and Kopf, 1980; Garbers, 1989) have informed much of the thinking in these areas.

\section{References}

ALESSI DR and COHEN P (1998). Mechanism of activation and function of protein kinase B. Curr. Opin. Genet. Dev., 8: 55-62.

ARNOULT C, CARDULLO RA, LEMOS JR and FLORMAN HM (1996b). Activation of mouse sperm T-type $\mathrm{Ca}^{2+}$ channels by adhesion to the egg zona pellucida. Proc. Natl. Acad. Sci. USA 93: 13004-13009.

ARNOULT C, KAZAM IG, VISCONTI PE, KOPF GS, VILLAZ M and FLORMAN HM (1999). Control of the low voltage-activated calcium channel of mouse sperm by egg ZP3 and by membrane hyperpolarization during capacitation. Proc. Nat/. Acad. Sci. USA, 96: 6757-6762.

ARNOULT C, LEMOS JR, FLORMAN HM (1997). Voltage-dependent modulation of T-type $\mathrm{Ca}^{2+}$ channels by protein tyrosine phosphorylation. EMBO J., 16: 1593-1599.

ARNOULT C, ZENG Y and FLORMAN HM (1996b). ZP3-dependent activation of sperm cation channels regulates acrosomal secretion during mammalian fertilization. J. Cell Biol., 134: 637-645.

BABCOCK DF and PFEIFFER DR (1987). Independent elevation of cytosolic [Ca ${ }^{2+}$ ] and $\mathrm{pH}$ of mammalian sperm by voltage-dependent and $\mathrm{pH}$-sensitive mechanisms. J. Biol. Chem., 262: 15041-15047.

BEZZERIDES VJ, RAMSEY IS, KOTECHA S, GREKA A and CLAPHAM DE (2004). Rapid vesicular translocation and insertion of TRP channels. Nat. Cell Biol., 6: 709-720.

BLEIL JD and WASSARMAN PM (1983). Sperm-egg interactions in the mouse: sequence of events and induction of the acrosome reaction by a zona pellucida glycoprotein. Dev. Biol., 95: 317-324.

BOSE A, ROBIDA S, FURCINITTIPS, CHAWLA A, FOGARTY K, CORVERA S and Czech MP (2004). Unconventional myosin Myo1c promotes membrane fusion in a regulated exocytic pathway. Mol. Cell Biol., 24: 5447-5458.

BRYAN JH (1974). Capacitation in the mouse: the response of murine acrosomes to the environment of the female reproductive tract. Biol. Reprod., 10: 414-421.

CANTLEY LC (2002). The phosphoinositide 3-kinase pathway. Science, 296: 1655- 
1657.

CASTELLANO LE, TREVINO CL, RODRIGUEZ D, SERRANO CJ, PACHECO J, TSUTSUMI V, FELIX, R and Darszon, A (2003). Transient receptor potential (TRPC) channels in human sperm: expression, cellular localization and involvement in the regulation of flagellar motility. FEBS Lett., 541: 69-74.

CHAN TO, RITTENHOUSE SE and TSICHLIS PN (1999). AKT/PKB and other D3 phosphoinositide-regulated kinases: kinase activation by phosphoinositidedependent phosphorylation. Annu. Rev. Biochem., 68: 965-1014.

CHEN CC, LAMPING KG, NUNO DW, BARRESI R, PROUTY SJ, LAVOIE JL, CRIBBS, LL, ENGLAND, SK, SIGMUND, CD, WEISS, RM, WILLIAMSON, RA, HILL, JA and CAMPBELL, KP. (2003). Abnormal coronary function in mice deficient in alpha1H T-type Ca2+ channels. Science, 302: 1416-1418.

CONNER SJ, LEFIEVRE L, HUGHES DC and BARRATT CL (2005). Cracking the egg: increased complexity in the zona pellucida. Hum. Reprod., 20: 1148-1152.

COUSIN MA, MALLADI CS, TAN TC, RAYMOND CR, SMILLIE KJ and ROBINSON PJ (2003). Synapsin I-associated phosphatidylinositol 3-kinase mediates synaptic vesicle delivery to the readily releasable pool. J. Biol. Chem., 278: 2906529071.

CROZET N (1984). Ultrastructural aspects of in vivo fertilization in the cow. Gamete Res., 10: 241-251.

CROZET N and DUMONT M (1984). The site of the acrosome reaction during in vivo penetration of the sheep oocyte. Gamete Res., 10: 97-105.

CUMMINS JM and YANAGIMACHI R (1982). Sperm-egg ratios and the site of the acrosome reaction during in vivo fertilization in the hamster. Gamete Res., 5: 239-256.

CUMMINS JM and YANAGIMACHI R (1986). Development of ability to penetrate the cumulus oophorus by hamster spermatozoa capacitated in vitro, in relation to the timing of the acrosome reaction. Gamete Res., 15: 187-212.

CZECH MP (2003). Dynamics of phosphoinositides in membrane retrieval and insertion. Annu. Rev. Physiol, 65: 791-815.

DARSZON A, ACEVEDO JJ, GALINDO BE, HERNANDEZ-GONZALEZ EO, NISHIGAKI T, TREVINO CL, WOOD, C and BELTRAN, C (2006). Sperm channel diversity and functional multiplicity. Reproduction., 131: 977-988.

DEMARCO IA, ESPINOSA F, EDWARDS J, SOSNIK J, DE LA VEGA-BELTRAN JL, HOCKENSMITH JW, KOPF, GS, DARSZON, A and VISCONTI, PE (2003). Involvement of a $\mathrm{Na}+/ \mathrm{HCO}-3$ cotransporter in mouse sperm capacitation. J. Biol. Chem., 278: 7001-7009.

DOUGLAS WW (1968). Stimulus-secretion coupling: the concept and clues from chromaffin and other cells. Brit. J. Pharm., 34: 451-474.

EISENBACH M and GIOJALAS LC (2006). Sperm guidance in mammals - an unpaved road to the egg. Nat. Rev. Mol. Cell Biol., 7: 276-285.

ENDO Y, LEE MA and KOPF GS (1988). Characterization of an islet-activating protein sensitive site in mouse sperm that is involved in the zona pellucidainduced acrosome reaction. Dev. Biol., 129: 12-24.

ESCOFFIER J, BOISSEAU S, SERRES C, CHEN CC, KIM D, STAMBOULIAN S, SHIN, HS, CAMPBELL, KP, DEWAARD, M and ARNOULT, C. (2007). Expression, localization and functions in acrosome reaction and sperm motility of $\mathrm{Ca}(\mathrm{V}) 3.1$ and $\mathrm{Ca}(\mathrm{V}) 3.2$ channels in sperm cells: an evaluation from $\mathrm{Ca}(\mathrm{V}) 3.1$ and $\mathrm{Ca}(\mathrm{V}) 3.2$ deficient mice. J. Cell Physiol, 212: 753-763.

EVANS GJ, BARCLAY JW, PRESCOTT GR, JO SR, BURGOYNE RD, BIRNBAUM MJ and MORGAN, A. (2006). Protein kinase B/Akt is a novel cysteine string protein kinase that regulates exocytosis release kinetics and quantal size. $J$. Biol. Chem., 281: 1564-1572.

FAYARD E, TINTIGNAC LA, BAUDRY A and HEMMINGS BA (2005). Protein kinase B/Akt at a glance. J. Cel/ Sci, 118: 5675-5678.

FELIX R (2005). Molecular physiology and pathology of $\mathrm{Ca}^{2+-}$ conducting channels in the plasma membrane of the mammalian sperm. Reprod., 129: 251-262.

FLORMAN HM (1994). Sequential focal and global elevations of sperm intracellular $\mathrm{Ca}^{2+}$ are initiated by the zona pellucida during acrosomal exocytosis. Dev. Biol., 165: $152-164$.

FLORMAN HM, CORRON ME, KIM TDH and BABCOCK DF (1992). Activation of voltage-dependent calcium channels of mammalian sperm is required for zona pellucida-induced acrosomal exocytosis. Dev. Biol., 152: 304-314.

FLORMAN HM and DUCIBELLA T (2006). Fertilization in Mammals. In: Neill JD (ed) Physiology of Reproduction, Elsevier: San Diego CA, pp 55-112.
FLORMAN HM and STOREY BT (1982). Mouse gamete interactions: the zona pellucida is the site of the acrosome reaction leading to fertilization in vitro. Dev. Biol., 91: 121-130.

FLORMAN HM, TOMBES RM, FIRST NL and BABCOCK DF (1989). An adhesionassociated agonist from the zona pellucida activates $\mathrm{G}$ protein-promoted elevations of internal $\mathrm{Ca}$ and $\mathrm{pH}$ that mediate mammalian sperm acrosoma exocytosis. Dev. Biol., 135: 133-146.

FRASER LR, ABEYDEERA LR and NIWA K (1995). Ca ${ }^{2+}$-regulating mechanisms that modulate bull sperm capacitation and acrosomal exocytosis as determined by chlortetracycline analysis. Mol. Reprod. Dev., 40: 233-241.

FUKAMI K (2002). Structure, regulation, and function of phospholipase $\mathrm{C}$ isozymes J. Biochem. (Tokyo), 131: 293-299.

FUKAMI K, NAKAO K, INOUE T, KATAOKA Y, KUROKAWA M, FISSORE RA NAKAMURA, K, MOTOYA, K, MIKOSHIBA, K, YOSHIDA, N and TAKENAWA, T. (2001). Requirement of phospholipase Cd4 for the zona pellucida-induced acrosome reaction. Science, 292: 920-923.

FUKAMI K, YOSHIDA M, INOUE T, KUROKAWA M, FISSORE RA, YOSHIDA N, MIKOSHIBA, K and TAKENAWA, T. (2003). Phospholipase Cd4 is required for Ca2+ mobilization essential for acrosome reaction in sperm. J. Cell Biol., 161: 79-88.

FUKUDA N, YOMOGIDA K, OKABE M and TOUHARA K (2004). Functional characterization of a mouse testicular olfactory receptor and its role in chemosensing and in regulation of sperm motility. J. Cell Sci., 117: 5835-5845.

GADELLA BM and VISCONTI PE (2006). Regulation of capacitation. In: De Jonge C, Barratt C. (eds) The Sperm Cell: Production, Maturation, Fertilization, Regeneration, Cambridge University Press: Cambridge, pp 134-169.

GARBERS DL (1989). Molecular basis of fertilization. Annu. Rev. Biochem., 58 719-742.

GARBERS DL and KOPF GS (1980). The regulation of spermatozoa by calcium and cyclic nucleotides. In: Greengard P, Robison G.A. (eds) Advances in Cyclic Nucleotide Research, Raven Press: New York, pp 251-306.

GRYNKIEWICZ G, POENIE M and TSIEN RY (1985). A new generation of $\mathrm{Ca}^{2+}$ indicators with greatly improved fluorescence properties. J. Biol. Chem., 260 3440-3450.

GWATKIN RBL (1976). Fertilization mechanisms in man and mammals. Plenum Pr.: New York.

GWATKIN RBL, CARTER HW and PATTERSON H (1976). Association of mammalian sperm with the cumulus cells and the zona pellucida studied by scanning electron microscopy. In: Johari H, Becker R.P. (eds) Scanning Electron Microscopy, Vol. 2, Part 2, IIT Research Inst.: Chicago, pp 379-384.

HARPER CV, BARRATT CL and PUBLICOVER SJ (2004). Stimulation of human spermatozoa with progesterone gradients to simulate approach to the oocyte: Induction of [Ca2+]i oscillations and cyclical transitions in flagellar beating. J. Biol. Chem.

HARPER CV and PUBLICOVER SJ (2005). Reassessing the role of progesterone in fertilization-compartmentalized calcium signalling in human spermatozoa? Hum. Reprod., 20: 2675-2680.

HERNANDEZ-GONZALEZ EO, TREVINO CL, CASTELLANO LE, DE LA VEGABELTRAN JL, OCAMPO AY, WERTHEIMER E, VISCONTI, PE and DARSZON, A. (2007). Involvement of Cystic Fibrosis Transmembrane Conductance Regulator in Mouse Sperm Capacitation. J. Biol. Chem., 282: 24397-24406.

HODGKINSON CP, MANDER A and SALE GJ (2005a). Identification of $80 \mathrm{~K}-\mathrm{H}$ as a protein involved in GLUT4 vesicle trafficking. Biochem. J., 388: 785-793.

HODGKINSON CP, MANDER A and SALE GJ (2005b). Protein kinase-zeta interacts with munc18c: role in GLUT4 trafficking. Diabetologia, 48: 1627-1636.

JIMENEZ-GONZALEZ C, MICHELANGELI F, HARPER CV, BARRATT CL and PUBLICOVER SJ (2005). Calcium signalling in human spermatozoa: a specialized 'toolkit' of channels, transporters and stores. Hum. Reprod. Update.

JIMENEZ-GONZALEZ C, MICHELANGELI F, HARPER CV, BARRATT CL and PUBLICOVER SJ (2006). Calcium signalling in human spermatozoa: a specialized 'toolkit' of channels, transporters and stores. Hum. Reprod. Update., 12 253-267.

JUNGNICKEL MK, MARRERO H, BIRNBAUMER L, LEMOS JR and FLORMAN $\mathrm{HM}$ (2001). Trp2 regulates entry of $\mathrm{Ca}^{2+}$ into mouse sperm triggered by egg ZP3. Nat. Cell Biol., 3: 499-502.

JUNGNICKEL MK, SUTTON KA, WANG Y and FLORMAN HM (2007). Phosphoi- 
nositide-dependent pathways in mouse sperm are regulated by egg ZP3 and drive the acrosome reaction. Dev. Biol., 304: 116-126.

KAMIYA R and WITMAN GB (1984). Submicromolar levels of calcium control the balance of beating between the two flagella in demembranated models of Chlamydomonas. J. Cell Biol., 98: 97-107.

KATZ B and MILEDI R (1967). The timing of calcium action during neuromuscular transmission. J. Physiol., 189: 535-544.

KISELYOV K, XU X, MOZHAYEVA G, KUO T, PESSAH I, MIGNERY G, ZHU, X, BIRNBAUMER, L and MUALLEM, S. (1998). Functional interaction between InsP3 receptors and store-operated Htrp3 channels. Nature, 396: 478-482.

LEYPOLD BG, YU CR, LEINDERS-ZUFALL T, KIM MM, ZUFALL F and AXEL R (2002). Altered sexual and social behaviors in trp2 mutant mice. Proc. Nat/. Acad. Sci. U.S.A. 99: 6376-6381.

LIZCANO JM and ALESSI DR (2002). The insulin signalling pathway. Curr. Biol., 12: R236-R238.

LOPEZ-GONZALEZ I, DE LA VEGA-BELTRÁN JL, SANTI CM, FLORMAN HM, FELIX R and DARSZON A (2001). Calmodulin antagonists inhibit T-type $\mathrm{Ca}^{2+}$ currents in mouse spermatogenic cells and the zona pellucida-induced sperm acrosome reaction. Dev. Biol., 236: 210-219.

MARQUEZ B and SUAREZ SS (2004). Different signaling pathways in bovine sperm regulate capacitation and hyperactivation. Biol. Reprod., 70: 1626-1633.

MONTELL C (2005). The TRP superfamily of cation channels. Sci. STKE., 2005: re3.

MUNOZ-GARAY C, DE LA VEGA-BELTRÁN JL, DELGADO R, LABARCA P, FELIX R and DARSZON A (2001). Inwardly rectifying $\mathrm{K}^{+}$channels in spermatogenic cells: functional expression and implication in sperm capacitation. Dev. Biol., 234: 261-274.

NAVARRO B, KIRICHOK Y and CLAPHAM DE (2007). KSper, a pH-sensitive K+ current that controls sperm membrane potential. Proc. Natl. Acad. Sci. USA 104: 7688-7692.

NEHER E, FERNANDEZ JM and LINDAU M (1987). The calcium dependence of vesicle exocytosis. Res. Publ. Assoc. Res. Nerv. Ment. Dis., 65: 103-110.

NEWSHOLME EA and START C (1973). Regulation of metabolism. John Wiley and Sons: Toronto.

NEWTON AC (2003). Regulation of the ABC kinases by phosphorylation: protein kinase $C$ as a paradigm. Biochem. J., 370: 361-371.

NILIUS B, OWSIANIK G, VOETS T and PETERS JA (2007). Transient receptor potential cation channels in disease. Physiol Rev., 87: 165-217.

O'TOOLE CM, ARNOULT C, DARSZON A, STEINHARDT RA and FLORMAN HM (2000). $\mathrm{Ca}(2+)$ entry through store-operated channels in mouse sperm is initiated by egg ZP3 and drives the acrosome reaction. Mol. Biol. Cell, 11: 15711584.

OSMAN RA, ANDRIA ML, JONES AD and MEIZEL S (1989). Steroid induced exocytosis: the human sperm acrosome reaction. Biochem. Biophys. Res. Commun., 160: 828-833.

PEREZ-REYES E (2003). Molecular physiology of low-voltage-activated t-type calcium channels. Physiol Rev., 83: 117-161.

PUBLICOVER S, HARPER CV and BARRATT C (2007). [Ca2+]i signalling in sperm-making the most of what you've got. Nat. Cell Biol., 9: 235-242.

PUTNEY JW (2007). Inositol lipids and TRPC channel activation. Biochem. Soc. Symp., 37-45.

QUILL TA, REN D, CLAPHAM DE and GARBERS DL (2001). A voltage-gated ion channel expressed specifically in spermatozoa. Proc. Natl. Acad. Sci. USA98: 12527-12531.

REBECCHI MJ and PENTYALA SN (2000). Structure, function, and control of phosphoinositide-specific phospholipase C. Physiol Rev., 80: 1291-1335.

REN D, NAVARRO B, PEREZ G, JACKSON AC, HSU S, SHI Q, TULLY, JL and CLAPHAM, DE. (2001). A sperm ion channel required for sperm motility and male fertility. Nature, 413: 603-609.

RHEE SG (2001). Regulation of phosphoinositide-specific phospholipase C. Annu. Rev. Biochem., 70: 281-312.

ROCKWELL PL and STOREY BT (2000). Kinetics of onset of mouse sperm acrosome reaction induced by solubilized zona pellucida: fluorimetric determination of loss of $\mathrm{pH}$ gradient between acrosomal lumen and medium monitored by dapoxyl (2-aminoethyl) sulfonamide and of intracellular $\mathrm{Ca}^{2+}$ changes monitored by fluo-3. Mol. Reprod. Dev., 55: 335-349.

ROLDAN ER, MURASE T and SHI QX (1994). Exocytosis in spermatozoa in response to progesterone and zona pellucida. Science, 266: 1578-1581.

ROLDAN ER and SHI QX (2007). Sperm phospholipases and acrosomal exocytosis. Front Biosci., 12: 89-104.

SALING PM, SOWINSKI J and STOREY BT (1979). An ultrastructural study of epididymal mouse spermatozoa binding to zonae pellucidae in vitro: sequential relationship to the acrosome reaction. J. Exp. Zool., 209: 229-238.

SALING PM and STOREY BT (1979). Mouse gamete interactions during fertilization in vitro. Chlortetracycline as a fluorescent probe for the mouse sperm acrosome reaction. J. Cell Biol., 83: 544-555.

SHIRAKAWA H and MIYAZAKI S (1999). Spatiotemporal characterization of intracellular $\mathrm{Ca}^{2+}$ rise during the acrosome reaction of mammalian spermatozoa induced by the zona pellucida. Dev. Biol., 208: 70-78.

SPEHR M, GISSELMANN G, POPLAWSKI A, RIFFELL JA, WETZEL CH, ZIMMER RK and HATT, H. (2003). Identification of a testicular odorant receptor mediating human sperm chemotaxis. Science, 299: 2054-2058.

STAMBOULIAN S, KIM D, SHIN HS, RONJAT M, DE WAARD M and ARNOULT C (2004). Biophysical and pharmacological characterization of spermatogenic Ttype calcium current in mice lacking the CaV3.1 (alpha1G) calcium channel: CaV3.2 (alpha1 $\mathrm{H})$ is the main functional calcium channel in wild-type spermatogenic cells. J. Cell Physiol, 200: 116-124.

STAMBOULIAN S, MOUTIN MJ, TREVES S, POCHON N, GRUNWALD D, ZORZATO F, DE WAARD, M, RONJAT, M and ARNOULT, C. (2005). Junctate, an inositol 1,4,5-triphosphate receptor associated protein, is present in rodent sperm and binds TRPC2 and TRPC5 but not TRPC1 channels. Dev. Biol., 286: 326-337.

STOWERS L, HOLY TE, MEISTER M, DULAC C and KOENTGES G (2002). Loss of sex discrimination and male-male aggression in mice deficient for TRP2. Science, 295: 1493-1500.

SUAREZ SS and HO HC (2003). Hyperactivation of mammalian sperm. Cell Mol. Biol. (Noisy. -le-grand), 49: 351-356.

SUAREZ SS, KATZ DF and OVERSTREET JW (1983). Movement characteristics and acrosomal status of rabbit spermatozoa recovered at the site and time of fertilization. Biol. Reprod., 29: 1277-1287.

SUAREZ SS, VAROSI SM and DAI X (1993). Intracellular calcium increases with hyperactivation in intact, moving hamster sperm and oscillates with the flagellar beat cycle. Proc. Natl. Acad. Sci. USA 90: 4660-4664.

SUTTON KA, JUNGNICKEL MK, WANG Y, CULLEN K, LAMBERT S and FLORMAN $\mathrm{HM}$ (2004). Enkurin is a novel calmodulin and TRPC channel binding protein in sperm. Dev. Biol., 274: 426-435.

TEVES ME, BARBANO F, GUIDOBALDI HA, SANCHEZR, MISKA W and GIOJALAS LC (2006). Progesterone at the picomolar range is a chemoattractant for mammalian spermatozoa. Fertil. Steril., 86: 745-749.

THALER CD and CARDULLO RA (1996). The initial molecular interaction between mouse sperm and the zona pellucida is a complex binding event. J. Biol. Chem., 271: 23289-23297.

TREVINO CL, FELIX R, CASTELLANO LE, GUTIERREZ C, RODRIGUEZ D, PACHECO J, LOPEZ-GONZALEZ, I, GOMORA, JC, TSUTSUMI, V, HERNANDEZ-CRUZ, A, FIORDELISIO, T., SCALING, AL and DARSZON, A. (2004). Expression and differential cell distribution of low-threshold $\mathrm{Ca}(2+)$ channels in mammalian male germ cells and sperm. FEBS Lett., 563: 87-92.

TREVINO CL, SERRANO CJ, BELTRAN C, FELIX R and DARSZON A (2001). Identification of mouse trp homologs and lipid rafts from spermatogenic cells and sperm. FEBS Lett., 509: 119-125.

VIARD P, BUTCHER AJ, HALET G, DAVIES A, NURNBERG B, HEBLICH F, and DOLPHIN, AC. (2004). PI3K promotes voltage-dependent calcium channel trafficking to the plasma membrane. Nat. Neurosci., 7: 939-946.

VISCONTI PE, BAILEY JL, MOORE GD, PAN D, OLDS-CLARKE P and KOPF GS (1995). Capacitation of mouse spermatozoa. I. Correlation between the capacitation state and protein tyrosine phosphorylation. Development, 121: 11291137.

WALENSKY LD and SNYDER SH (1995). Inositol 1,4,5-trisphosphate receptors selectively localized to the acrosomes of mammalian sperm. J. Cell Biol., 130: 857-869. 
WARD CR, KOPF GS and STOREY BT (1994a). Solubilization and partial purification from mouse sperm membranes of the specific binding activity for 3 quinuclidinyl benzilate, a potent inhibitor of the zona pellucida-induced acrosome reaction. Mol. Reprod. Dev., 39: 423-432.

WARD CR, STOREY BT and KOPF GS (1994b). Selective activation of Gi1 and Gi2 in mouse sperm by the zona pellucida, the egg's extracellular matrix. J. Biol. Chem., 269: 13254-13258.

WASSARMAN PM, JOVINE L and LITSCHER ES (2001). A profile of fertilization in mammals. Nat. Cell Biol., 3: E59-E64.

WENNEMUTH G, WESTENBROEK RE, XU T, HILLE B and BABCOCK DF (2000). $\mathrm{Ca}_{\mathrm{v}} 2.2$ and $\mathrm{Ca}_{\mathrm{v}} 2.3$ (N- and R-type) $\mathrm{Ca}^{2+}$ Channels in Depolarization-evoked Entry of $\mathrm{Ca}^{2+}$ into Mouse Sperm. J. Biol. Chem., 275: 21210-21217.
WESTENBROEK RE and BABCOCK DF (1999). Discrete regional distributions suggest diverse functional roles of calcium channel alpha1 subunits in sperm. Dev. Biol., 207: 457-469.

XU WM, SHI QX, CHEN WY and ZHOU CX (2007). CFTR is vital to sperm fertilizing capacity and male fertility. Proc. Nat/. Acad. Sci. USA 104: 9816-9821.

YANAGIMACHI R (1994). Mammalian fertilization. In: Knobil E, Neill J.D. (eds) The Physiology of Reproduction, Raven Press, Ltd.: New York, pp 189-317.

YANAGIMACHI R and USUI N (1974). Calcium dependence of the acrosome reaction and activation of guinea pig spermatozoa. Exp. CellRes., 89: 161-174.

ZENG Y, CLARK EN and FLORMAN HM (1995). Sperm membrane potential: hyperpolarization during capacitation regulates zona pellucida-dependent acrosomal secretion. Dev. Biol., 171: 554-563.

\section{Related, previously published Int. J. Dev. Biol. articles}

See our recent Special Issue Developmental Biology in Poland edited by Tarkowski, Maleszewski and Kloc at: http://www.ijdb.ehu.es/web/contents.php?vol=52\&issue=2-3

See our recent Special Issue Ear Development edited by Fernando Giraldez and Bernd Fritzsch at: http://www.ijdb.ehu.es/web/contents.php?vol=51\&issue=6-7

Mammalian fertilization:the egg's multifunctional zona pellucida

Paul M. Wassarman and Eveline S. Litscher

Int. J. Dev. Biol. (2008) 52: 665-676

Regionalized calcium signaling in zebrafish fertilization

Dipika Sharma and William H. Kinsey

Int. J. Dev. Biol. (2008) 52: 561-570

Defective calcium release during in vitro fertilization of maturing oocytes of LT/Sv mice

Karolina Archacka, Anna Ajduk, Pawel Pomorski, Katarzyna Szczepanska, Marek Maleszewski and Maria A. Ciemerych Int. J. Dev. Biol. (2008) 52: doi: 10.1387/ijdb.072397ka

Ca2+-independent protein kinase $\mathbf{C}$ signalling in mouse eggs during the early phases of fertilization. Carla Tatone, Simona Delle Monache, Antonella Francione, Luisa Gioia, Barbara Barboni and Rosella Colonna Int. J. Dev. Biol. (2003) 47: 327-333

CpZPC, a newt ZPC molecule, localizes to the inner surface of the egg envelope. Youko Makabe-Kobayashi, Etsuko Kudaira, Akihiko Watanabe and Kazuo Onitake Int. J. Dev. Biol. (2003) 47: 51-58

Association of egg zona pellucida glycoprotein mZP3 with sperm protein sp56 during fertilization in mice.

$\mathrm{N}$ Cohen and P M Wassarman

Int. J. Dev. Biol. (2001) 45: 569-576

Fertilization triggers activation of Fyn kinase in the zebrafish egg.

W Wu and W H Kinsey

Int. J. Dev. Biol. (2000) 44: 837-841

Analysis of polysulfate-binding domains in porcine proacrosin, a putative zona adhesion protein from mammalian spermatozoa.

S Jansen, M Quigley, W Reik and R Jones

Int. J. Dev. Biol. (1995) 39: 501-510

Egg-jelly signal molecules for triggering the acrosome reaction in starfish spermatozoa.

M Hoshi, T Nishigaki, A Ushiyama, T Okinaga, K Chiba and M Matsumoto

Int. J. Dev. Biol. (1994) 38: 167-174

Failure of differentiation of the nuclear-perinuclear skeletal complex in the roundheaded human spermatozoa.

D Escalier

2006 ISI ${ }^{\star \star}$ Impact Factor $=3.577^{\star \star}$

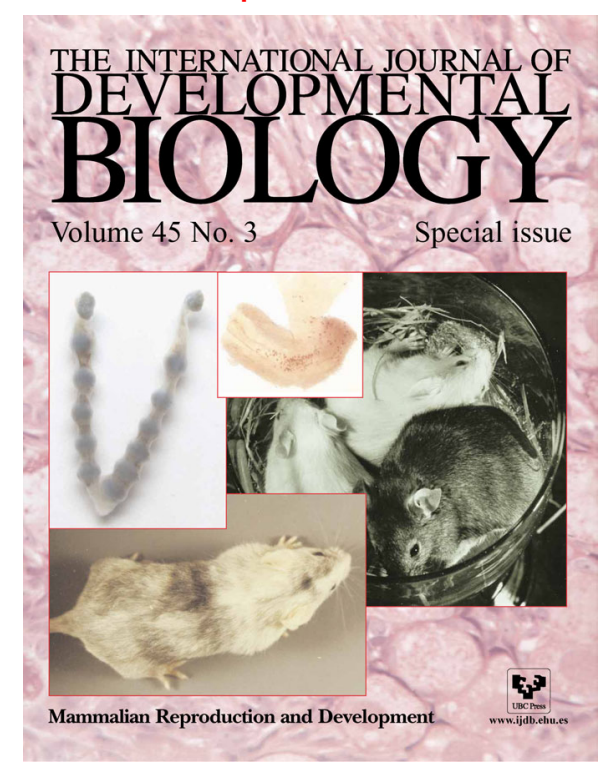

Int. J. Dev. Biol. (1990) 34: 287-297 